\section{Corrección en artículo sobre hipertensión en adultos mexicanos}

Estimado editor: En relación con el artículo "Hypertension in Mexican adults: results from the National Health and Nutrition Survey 2006", aparecido en Salud Pública de México, ${ }^{1}$ nos gustaría señalar que por error presentamos prevalencias utilizando el punto de corte de la clasificación del ATP III² para definir hipertensión arterial, y no de la clasificación de JNC $7,{ }^{3}$ como se señala en el texto. Hemos recalculado las prevalencias de hipertensión en México, así como los cuadros y figuras del artículo, para poder hacer comparaciones con la encuesta anterior y con las futuras utilizando los mismos puntos de corte (figuras 1 y 2 , cuadro I).

Con esta modificación, la prevalencia de hipertensión en México fue de $31.6 \%$, cifra menor a la originalmente presentada.

Por lo anterior, pedimos una disculpa a los lectores y mucho agradecemos que esta información pueda ser distribuida por ustedes.

Simón Barquera, MD, PhD, Ismael Campos, MSc, Lucía Hernández, MSc, Salvador Villalpando, PhD, César Rodríguez, MD, Ramón Durazo, PhD, Carlos Aguilar, MC.

\section{Referencias}

I. Barquera S, Campos-Nonato I, HernándezBarrera L, Villalpando S, Rodríguez-Gilabert C, Durazo-Arvizú R, et al. Hypertension in Mexican adults: results from the National Health and $\mathrm{Nu}$ trition Survey 2006. Salud Publica Mex 2010;52 suppl I:S63-S7I.

2. Third Report of the National Cholesterol Education Program (NCEP) Expert Panel on Detection, Evaluation, and Treatment of High Blood Cholesterol in Adults (Adult Treatment Panel III) final report. Circulation 2002;106(25):3।43-342I. 3. Chobanian A, Bakris G, Black H. The Seventh Report of the Joint National Committee on Prevention, Detection, Evaluation, and Treatment of High Blood Pressure: the JNC 7 report. JAMA 2003;289:2560-2572.

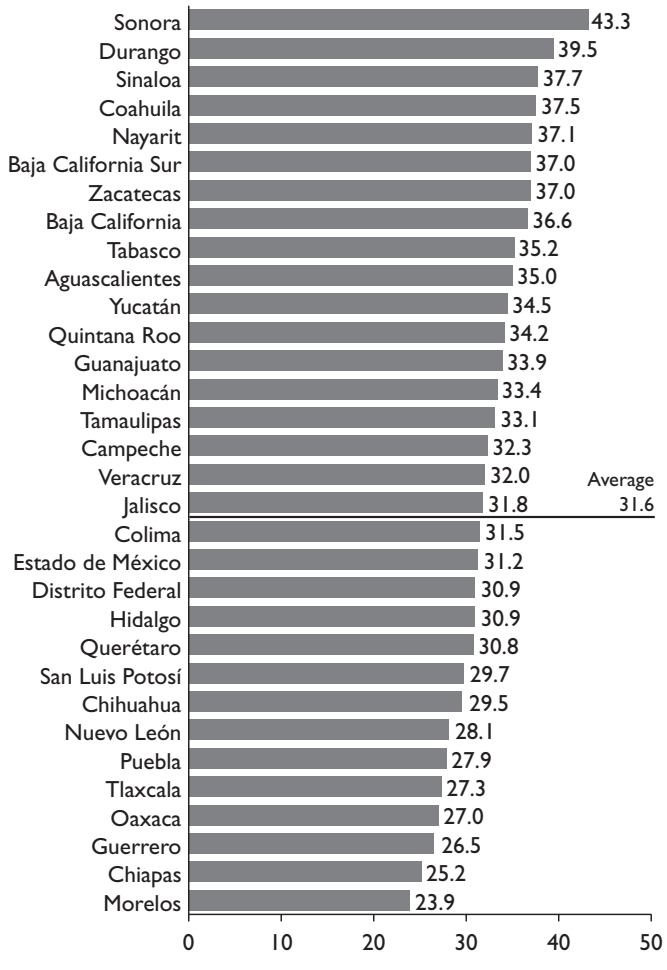

* JNC7 cut-off points. SBP $\geq 140$ ० DBP $\geq 90 \mathrm{mmHg}$ or pharmacological treatment for hypertension

Data adjusted for the survey complex design

Figure I. Prevalence of hypertension in Mexican adults by state. Mexico, ENSANUT 2006*

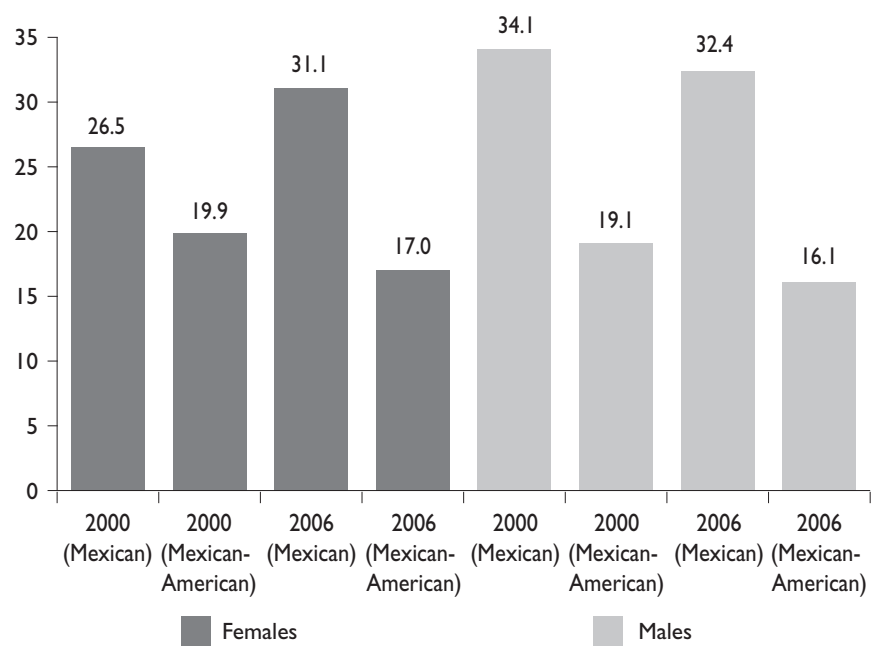

Figure 2. Changes in the prevalence of hypertension in MexiCAN ADULTS (MHS 2000, ENSANUT 2006 AND NHANES 1999-2000, NHANES 2005-2006) 
Table I

SOCIODEMOGRAPHIC CHARACTERISTICS, ANTHROPOMETRY AND PREVIOUSLY DIAGNOSED CHRONIC DISEASES IN ADULT $\geq 20$ YeARS With Hypertension. Mexico, ENSANUT 2006*

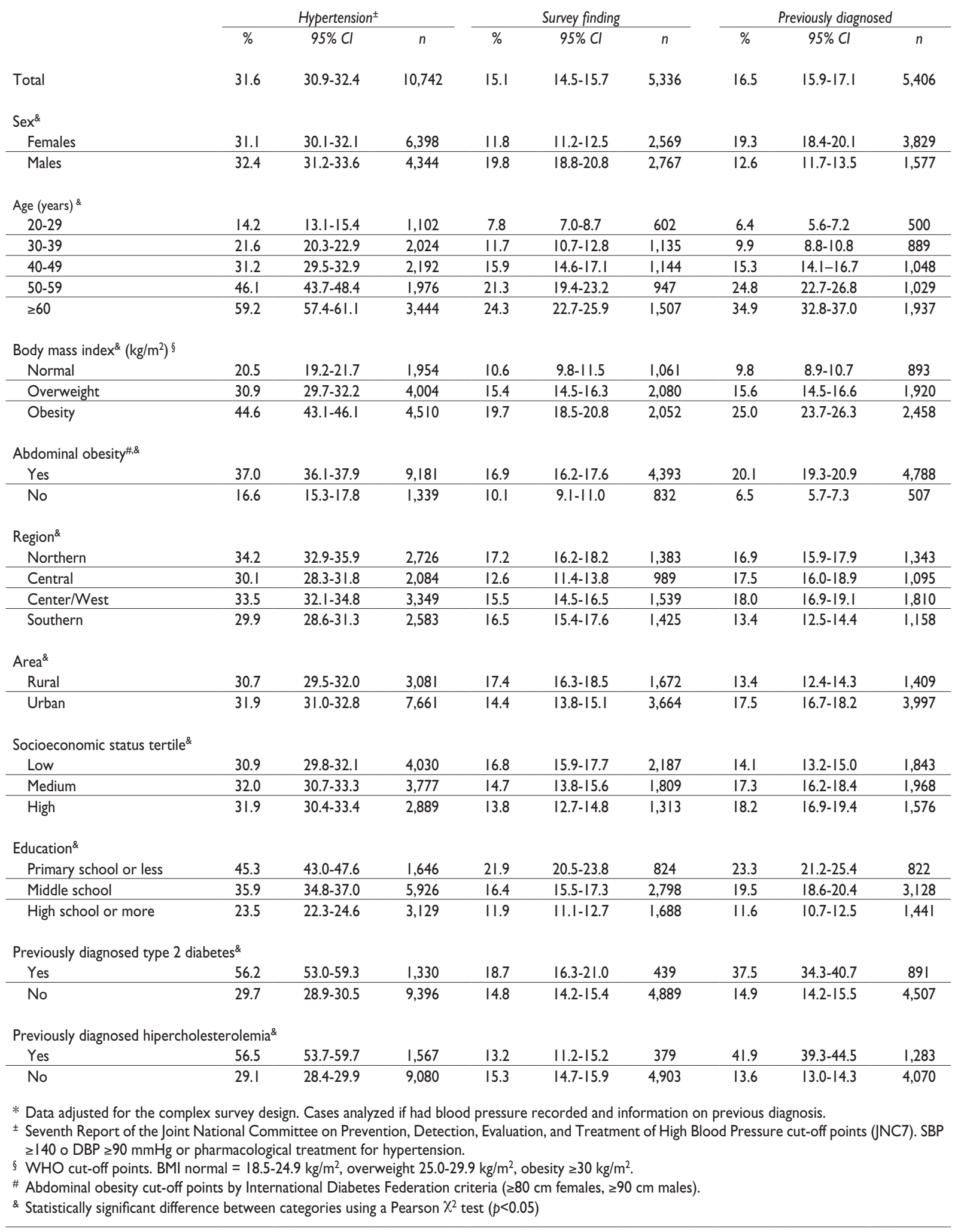

